\title{
Survey response rates: national and regional differences in a European multicentre study of vertebral osteoporosis
}

T W O'Neill, D Marsden, C Matthis, H Raspe, A J Silman, and the European Vertebral Osteoporosis Study Group*

\begin{abstract}
Study objective - This analysis aimed to compare the response rates of those invited to attend for screening in a multicentre, multinational study within Europe. Design - This was a population survey. Setting - Thirty four centres in 16 European countries.

Subjects - Men and women aged 50 years and over were recruited from population based sampling frames to participate in a prevalence survey of osteoporosis. Subjects were invited by post to attend for radiological screening and interview, and non-responders were followed up by repeat mailing.
\end{abstract}

Results - There was a substantial variation between centres in response rates: the mean was $49 \%$ and the range $5-83 \%$. Adjusting for those known to have died or moved house did not affect the overall ranking. The response rates to each mailing also varied between centres: first mailing $45 \%$ (range $5-83 \%$ ) and second mailing mean $10 \%$ (range $0-23 \%$ ). The response rates varied in relation to age and sex and were higher in women than men. Rates fell gradually with age in women but rose in men until the age of 65 years. Response rates varied regionally. These were highest in countries from northern Europe and lowest in southern European countries, but there was wide variation both within regions and within countries.

Conclusions - Multicentre, multinational studies within Europe will probably become increasingly popular. In this study, despite a standardised approach, the range in response rates between centres both within and between countries was substantial. Attempts at cross national standardisation in survey design can have only a limited effect on yielding uniformity in response.

\section{( $\mathcal{F}$ Epidemiol Community Health 1995;49:87-93)}

Multicentre multinational studies play an increasingly important role in epidemiological research. The larger sample size that may be recruited and the variability in exposures within the populations studied allows for increased power to detect risk differences between groups. One of the main methodological issues in these studies is assuring the comparability of the data obtained. One specific problem relates to non-response bias - it is generally perceived that the higher the response rate the less the likelihood of non-response bias. In multinational epidemiological studies, however, the extent to which response rates can be increased may be limited because of social, demographic, cultural, and other factors in the different populations studied. We carried out a multicentre prevalence survey of vertebral osteoporosis in 18 European countries which necessitated attendance at a local clinic for radiological screening and lifestyle interview. Attempts were made to standardise the methods used for population sampling and recruitment. In this report the response rates in individual centres are compared together with the influence of age, sex, and geographical region. In addition, the effect of local "structural" differences in the survey technique were considered.

\section{Methods}

PARTICIPATING CENTRES

Thirty six centres from 18 European countries participated in the European vertebral osteoporosis study (EVOS); two used a different method of recruitment, however, and will not be considered further here. Data on response rates were therefore available in 34 centres. Participating centres were recruited on the basis of their interest in osteoporosis research, access to a population based sample, and facilities to perform an epidemiological survey. In addition, each centre required sufficient financial and administrative resources to complete the data collection within their own centre.

POPULATION SAMPLING

At the beginning of the study, the local coordinator for each centre received instruction in sampling methods, including how to access and obtain a representative sample of individuals aged 50 and over from a population based sampling frame. Instruction took the form of a workshop in Manchester, to which all of the participants were invited, and individual discussions at each centre with a member of the epidemiological coordinating team. The nature of the sampling frames subsequently used in the individual centres are shown in table 1. The population registers were, to the knowledge of the participating centres, those most current at the time of survey. In each 
Table 1 Study regions and centres

\begin{tabular}{|c|c|c|}
\hline $\begin{array}{l}\text { Northern Europe } \\
\text { Oslo, Norway } \\
\text { Population register, Oslo } \\
\text { Delayed appointment }\end{array}$ & $\begin{array}{l}\text { Malmö, Sweden } \\
\text { Population register, Malmö } \\
\text { Fixed appointment }\end{array}$ & . \\
\hline $\begin{array}{l}\text { Western Europe } \\
\text { Graz, Austria } \\
\text { Electoral register, Graz } \\
\text { Delayed appointment }\end{array}$ & $\begin{array}{l}\text { Aberdeen, } U K \\
\text { Community health index } \\
\text { (Derived from FHSA lists and general }\end{array}$ & \\
\hline $\begin{array}{l}\text { Leuven, Belgium } \\
\text { Electoral register, } 3 \text { towns near Leuven }\end{array}$ & $\begin{array}{l}\text { practice records) } \\
\text { Fixed appointment }\end{array}$ & \\
\hline Fixed appointment & Trun, UK & \\
\hline $\begin{array}{l}\text { Montçeau-Les-Mines, France } \\
\text { Health insurance organisation }\end{array}$ & $\begin{array}{l}\text { General practice register } \\
\text { Fixed appointment }\end{array}$ & \\
\hline Fixed appointment & Cambridge, UK & \\
\hline $\begin{array}{l}\text { Bath, UK } \\
\text { General practice register }\end{array}$ & $\begin{array}{l}\text { General practice register } \\
\text { Fixed appointment }\end{array}$ & \\
\hline Delayed appointment & Sheffield, UK & \\
\hline $\begin{array}{l}\text { Harrow, } U K \\
\text { General practice register } \\
\text { Fixed appointment }\end{array}$ & $\begin{array}{l}\text { General practice register } \\
\text { Fixed appointment }\end{array}$ & \\
\hline $\begin{array}{l}\text { Eastern Europe } \\
\text { Moscow, Russia } \\
\text { Population register - Moscow } \\
\text { Delayed appointment }\end{array}$ & $\begin{array}{l}\text { Warsaw, Poland } \\
\text { Health register } \\
\text { Fixed appointment }\end{array}$ & \\
\hline $\begin{array}{l}\text { Piestany, Slovakia } \\
\text { Electoral register, Piestany } \\
\text { Fixed appointment }\end{array}$ & $\begin{array}{l}\text { Sczecin, Poland } \\
\text { Health register } \\
\text { Fixed appointment }\end{array}$ & \\
\hline $\begin{array}{l}\text { Prague, Czech Republic } \\
\text { Electoral register, Prague } \\
\text { Fixed appointment }\end{array}$ & $\begin{array}{l}\text { Zagreb, Croatia } \\
\text { Electoral register } \\
\text { Open appointment }\end{array}$ & \\
\hline \multicolumn{2}{|l|}{$\begin{array}{l}\text { Budapest, Hungary } \\
\text { Population register, Budapest III } \\
\text { Fixed appointment }\end{array}$} & \\
\hline $\begin{array}{l}\text { Southern Europe } \\
\text { Athens, Greece } \\
\text { Electoral register, Psyhiko (district of Athens) } \\
\text { Asked to contact centre to make appointment }\end{array}$ & $\begin{array}{l}\text { Barcelona, Spain } \\
\text { Electoral register } \\
\text { Fixed appointment }\end{array}$ & \\
\hline $\begin{array}{l}\text { Siena, Italy } \\
\text { Social security register }\end{array}$ & $\begin{array}{l}\text { Madrid, Spain } \\
\text { Social security register }\end{array}$ & \\
\hline Fixed appointment & Las Palmas, Spain & \\
\hline $\begin{array}{l}\text { Milan, Italy } \\
\text { Social security register }\end{array}$ & & \\
\hline Fixed appointment & Oviedo, Spain & \\
\hline $\begin{array}{l}\text { Oporto, Portugal } \\
\text { General practice register } \\
\text { Fixed appointment }\end{array}$ & $\begin{array}{l}\text { Health register } \\
\text { Fixed appointment }\end{array}$ & \\
\hline $\begin{array}{l}\text { German centres } \\
\text { Bochum, Heidelberg, Berlin Potsdam, Berlin } \\
\text { Steglitz, } \\
\text { Berlin Charite, fena, Erfurt, Lubeck } \\
\text { Population based registers } \\
\text { Delayed appointment }\end{array}$ & & \\
\hline
\end{tabular}

See text for details of type of appointment system.

centre a pilot study was undertaken on 50 subjects: the response rate from this was used to determine the size of the number to be approached in the main study to achieve the target recruitment. Stratified sampling was used with a target number of responders of 50 men and 50 women in each of six age strata, 50-54, 55-59, 60-64, 65-69, 70-74, and 75 years and over. In practice, most $(>75 \%)$ of the subjects in the $75+$ stratification group were aged between 75 and 79 , with only $1 \%$ of the total study population aged 85 years or over. Subjects were invited by letter to attend for screening at a local clinic. Screening involved completing an interviewer administered questionnaire and lateral spinal radiographs.

The eight German centres used a different screening strategy. The subjects were selected from population registers and sent a short questionnaire by post; only those who responded to this (up to two reminders) and indicated a willingness to take part in the main survey were invited, either by telephone or letter, to attend for screening.

\section{LETTER OF INVITATION}

Broad guidelines, including an example letter, were given to each centre. These included the following: the letter should be brief (usually less than one page) and include details, in lay language, of (i) the purpose of the study, (ii) what participation in the study would entail, (iii) why the subject had been chosen for participation, (iv) confirmation that any examinations performed would be free of charge, and (v) reassurance that the data obtained would be confidential. Where possible, a stamped addressed envelope was to be used, and a reply slip enclosed with the letter of invitation. Each centre, however, was ultimately responsible for the design of its own letter, and for arranging a convenient appointment system. A follow up letter was sent to those who failed to attend after the first letter (normally within a one month period). A record book which recorded details of all those who were invited and when they attended for interview was kept at each centre. The record book was forwarded to the coordinating centre at the end of the study.

In some centres those subjects no longer resident at the address on the register or those who had recently died were identified from post office returns, though the quality of these data varied between the different participating centres. For practical reasons, no detailed home follow up of non-responders was performed.

\section{ANALYSIS}

Statistical analysis was performed using SPSS/ $P C$ software. The response rates were calculated in 10 year age and sex bands in relation to centre, country, and region, both overall and separately for the first and second invitation. The response rates were also corrected for people known to have died or moved house. To permit overall comparisons between centres, the response rates were standardised to a theoretical population distribution with 100 people in each 10 year age and sex band. To explore the effect of geography on response rates, the data from centres were pooled into four regions representing broadly north, south, east, and west Europe (see table 1).

\section{Results}

DEMOGRAPHIC DETAILS

The 26 centres outside Germany recruited 11413 subjects and the eight German centres 4456 subjects.

\section{SURVEY TECHNIQUE}

Most centres followed the guidelines with regard to the content of the letters of invitation. There was some variation in the appointment system used (see table 1). Most centres used a "fixed" appointment system where the time of the interview was included in the original letter of invitation, though this could be changed by the subject if unsuitable. Other appointment methods used included: a delayed system where the subject was initially required to indicate 
Table 2 Overall response rates for each centre

\begin{tabular}{|c|c|c|c|c|c|c|}
\hline Centre & (Country) & No surveyed & No of responses & $\begin{array}{l}\text { Crude rate } \\
(\%)\end{array}$ & $\begin{array}{l}\text { Died or moved } \\
\text { house }\end{array}$ & $\begin{array}{l}\text { Corrected rate } \\
(\%)\end{array}$ \\
\hline $\begin{array}{l}\text { Oporto } \\
\text { Malmö } \\
\text { Budapest } \\
\text { Montçeau } \\
\text { Oslo } \\
\text { Moscow } \\
\text { Piestany } \\
\text { Warsaw } \\
\text { Aberdeen } \\
\text { Cambridge } \\
\text { Zagreb } \\
\text { Szczecin } \\
\text { Bath } \\
\text { Prague } \\
\text { Truro } \\
\text { Sheffield } \\
\text { Harrow } \\
\text { Oviedo } \\
\text { Graz } \\
\text { Leuven } \\
\text { Siena } \\
\text { Barcelona } \\
\text { Athens } \\
\text { Las Palmas } \\
\text { Madrid } \\
\text { Milan }\end{array}$ & $\begin{array}{l}\text { (Portugal) } \\
\text { (Sweden) } \\
\text { (Hungary) } \\
\text { (France) } \\
\text { (Norway) } \\
\text { (Russia) } \\
\text { (Slovakia) } \\
\text { (Poland) } \\
\text { (UK) } \\
\text { (UK) } \\
\text { (Croatia) } \\
\text { (Poland) } \\
\text { (UK) } \\
\text { (Czech Rep) } \\
\text { (UK) } \\
\text { (UK) } \\
\text { (UK) } \\
\text { (Spain) } \\
\text { (Austria) } \\
\text { (Belgium) } \\
\text { (Italy) } \\
\text { (Spain) } \\
\text { (Greece) } \\
\text { (Spain) } \\
\text { (Spain) } \\
\text { (Italy) }\end{array}$ & $\begin{array}{r}251 \\
764 \\
908 \\
846 \\
942 \\
813 \\
1040 \\
996 \\
835 \\
582 \\
400 \\
973 \\
395 \\
888 \\
890 \\
718 \\
734 \\
1702 \\
1395 \\
1117 \\
1696 \\
498 \\
2467 \\
1934 \\
5695 \\
1500\end{array}$ & $\begin{array}{r}209 \\
598 \\
641 \\
562 \\
599 \\
520 \\
637 \\
610 \\
500 \\
346 \\
226 \\
535 \\
213 \\
458 \\
454 \\
375 \\
327 \\
624 \\
618 \\
453 \\
606 \\
87 \\
400 \\
272 \\
465 \\
78\end{array}$ & $\begin{array}{r}83 \cdot 3 \\
78 \cdot 3 \\
70 \cdot 6 \\
66 \cdot 4 \\
63 \cdot 6 \\
64 \cdot 0 \\
61 \cdot 3 \\
61 \cdot 2 \\
59 \cdot 9 \\
59 \cdot 5 \\
56 \cdot 5 \\
55 \cdot 0 \\
53 \cdot 9 \\
51 \cdot 6 \\
51 \cdot 0 \\
52 \cdot 2 \\
44 \cdot 6 \\
36 \cdot 7 \\
44 \cdot 3 \\
40 \cdot 6 \\
35 \cdot 7 \\
17 \cdot 5 \\
16 \cdot 2 \\
14 \cdot 1 \\
8 \cdot 2 \\
5 \cdot 2\end{array}$ & $\begin{array}{r}- \\
- \\
- \\
26 \\
31 \\
23 \\
69 \\
20 \\
13 \\
1 \\
4 \\
- \\
5 \\
29 \\
25 \\
- \\
20 \\
319 \\
25 \\
14 \\
- \\
- \\
- \\
- \\
25 \\
47\end{array}$ & $\begin{array}{r}83 \cdot 3 \\
78 \cdot 3 \\
70 \cdot 6 \\
68 \cdot 5 \\
65 \cdot 8 \\
65 \cdot 8 \\
65 \cdot 6 \\
62 \cdot 5 \\
60 \cdot 8 \\
59 \cdot 6 \\
57 \cdot 1 \\
55 \cdot 0 \\
54 \cdot 6 \\
53 \cdot 3 \\
52 \cdot 5 \\
52 \cdot 2 \\
45 \cdot 8 \\
45 \cdot 1 \\
45 \cdot 1 \\
41 \cdot 1 \\
35 \cdot 7 \\
17 \cdot 5 \\
16 \cdot 2 \\
14 \cdot 1 \\
8 \cdot 2 \\
5 \cdot 4\end{array}$ \\
\hline $\begin{array}{l}\text { EVOS total } \\
\text { Centre mean }\end{array}$ & & $\begin{array}{r}30979 \\
1192\end{array}$ & $\begin{array}{r}11413 \\
439\end{array}$ & $\begin{array}{l}36 \cdot 8 \\
48 \cdot 1\end{array}$ & $\begin{array}{r}696 \\
41\end{array}$ & $\begin{array}{l}37 \cdot 7 \\
49 \cdot 2\end{array}$ \\
\hline
\end{tabular}

their willingness to participate before an appointment was arranged either by letter or telephone (Bath/Graz/Oslo/Moscow); an "open" appointment system where the subject was invited to attend for interview at his/her convenience between certain pre-arranged times (Zagreb); and a system where subjects were invited to contact the centre to make arrangements for interview (Athens).

The timing of the interview varied between centres from early morning to late afternoon, though there was substantial within centre variation in the timing of individual interviews. In addition, there was variation both within and between centres in terms of the distance which a subject was required to travel for interview and $x$ ray, though other factors, including the degree of urbanisation and adequacy of public transport systems, influenced the total time taken to travel for interview. Because of the methodological difficulties in collecting information on these parameters in a standardised fashion between individuals across the different participating centres, this was not routinely recorded.

\section{RESPONSE RATES}

The response rates for the non-German centres are shown in table 2 . The overall response rate was $38 \%$; the mean centre response rate was $49 \%$ with a wide range $(5-83 \%)$ between centres; and the median centre response was $54 \%$. Only in Oviedo was a sufficient number of post office returns received for those known to have died or moved house to affect the overall response rates by more than $5 \%$. The influence of age and sex on response rates is shown by centre in table 3. Detailed information concerning non-responders was unavailable from both Zagreb and Harrow. Response rates declined in women from the age of 50 years, but in men they rose from the age of 50 to a maximum at age 60-69 years followed by a decline after this age. There was some variation between centres in these patterns, with, for example, much less evidence of a female:male excess in the northern and some eastern European centres. Not all centres recruited equal numbers in each of the stratification bands. To take account of this we standardised response rates using a theoretical population distribution with 100 people in each age and sex band. There were, however, no important differences in response rates after standardisation.

The results of the first and second time responders are shown in table 4. In this analysis, the response to the second letter varied considerably, ranging from $0-23 \%$, with evidence of strong geographical variation. Thus, in some of the southern European centres the actual number of individuals recruited as a result of the second mailing represented a substantial proportion of the final sample studied. Overall the northern European centres had substantially higher response rates and the southern centres substantially lower rates than the other regions (figure). This was true for all age and sex groups (table 5). Similarly, although the proportion of those recruited as a result of a second mailing was highest in the southern European centres the actual second time response rates in all regions reflected the response rates overall.

\section{STRUCTURAL INFLUENCES}

Most centres used a fixed appointment system (table 1) and it is therefore difficult to assess the influence of the appointment system on the response rate. There was some evidence to suggest that health based registers are associated with higher response rates. Thus, Oporto and Oviedo, the two southern European centres using such registers, had overall response rates substantially higher than the southern European average. Furthermore, Graz and Leuven, which relied on electoral/ population registers, recorded lower overall response rates than the remaining western European centres which used health based registers. 
Table 3 Response rates in relation to age and sex for each centre

\begin{tabular}{|c|c|c|c|c|c|c|c|c|c|}
\hline \multirow[t]{2}{*}{ Centre } & \multicolumn{8}{|c|}{ Age and sex groupings } & \multirow[b]{2}{*}{ Standardised $\dagger$} \\
\hline & $\begin{array}{l}50-59 y \\
M(\%)\end{array}$ & $F(\%)$ & $\begin{array}{l}60-69 y \\
M(\%)\end{array}$ & $F(\%)$ & $\begin{array}{l}70+y \\
M(\%)\end{array}$ & $F(\%)$ & $\begin{array}{l}\text { All ages } \\
M(\%)\end{array}$ & $F(\%)$ & \\
\hline Oporto & $87 \cdot 5$ & $92 \cdot 3$ & $89 \cdot 5$ & $80 \cdot 0$ & $69 \cdot 2$ & $73 \cdot 0$ & 83.9 & $82 \cdot 7$ & 81.9 \\
\hline Malmö & $80 \cdot 7$ & $76 \cdot 6$ & $85 \cdot 3$ & $82 \cdot 5$ & $75 \cdot \overline{7}$ & $71 \cdot 0$ & $80 \cdot 3$ & $76 \cdot 3$ & $78 \cdot 6$ \\
\hline Budapest & $64 \cdot 2$ & $73 \cdot 2$ & $66 \cdot 1$ & $74 \cdot 5$ & 71.9 & $75 \cdot 2$ & $67 \cdot 0$ & $74 \cdot 2$ & $70 \cdot 9$ \\
\hline Montçeau & $81 \cdot 7$ & $83 \cdot 6$ & $70 \cdot 3$ & $79 \cdot 0$ & $68 \cdot 0$ & $40 \cdot 6$ & $72 \cdot 7$ & $64 \cdot 4$ & $70 \cdot 5$ \\
\hline Oslo & $73 \cdot 1$ & $76 \cdot 2$ & $70 \cdot 8$ & 63.9 & $60 \cdot 2$ & $56 \cdot 0$ & $67 \cdot 4$ & $64 \cdot 2$ & $66 \cdot 7$ \\
\hline Piestany & $68 \cdot 8$ & $72 \cdot 2$ & $71 \cdot 8$ & $66 \cdot 0$ & $68 \cdot 2$ & $51 \cdot 2$ & $69 \cdot 6$ & $62 \cdot 0$ & $66 \cdot 4$ \\
\hline Moscow & $58 \cdot 1$ & $87 \cdot 3$ & $57 \cdot 8$ & $77 \cdot 2$ & $48 \cdot 6$ & $66 \cdot 9$ & $55 \cdot 4$ & $76 \cdot 3$ & $66 \cdot 0$ \\
\hline Cambridge & $56 \cdot 8$ & 71.9 & $65 \cdot 9$ & $64 \cdot 8$ & $71 \cdot 4$ & $63 \cdot 3$ & $65 \cdot 8$ & $66 \cdot 1$ & $65 \cdot 7$ \\
\hline Warsaw & 61.9 & $65 \cdot 6$ & $62 \cdot 1$ & $59 \cdot 2$ & $65 \cdot 8$ & $61 \cdot 1$ & $63 \cdot 2$ & $61 \cdot 8$ & $62 \cdot 6$ \\
\hline Aberdeen & $47 \cdot 4$ & $75 \cdot 2$ & $65 \cdot 5$ & $64 \cdot 6$ & 54.5 & $57 \cdot 1$ & $56 \cdot 1$ & $65 \cdot 8$ & $60 \cdot 7$ \\
\hline Bath & $56 \cdot 2$ & $64 \cdot 2$ & $61 \cdot 4$ & $68 \cdot 4$ & $44 \cdot 6$ & $36 \cdot 6$ & $53 \cdot 8$ & $55 \cdot 4$ & $55 \cdot 2$ \\
\hline Szczecin & $55 \cdot 6$ & $67 \cdot 8$ & $62 \cdot 3$ & $64 \cdot 2$ & $30 \cdot 6$ & $49 \cdot 3$ & $49 \cdot 9$ & $60 \cdot 6$ & $55 \cdot 0$ \\
\hline Prague & $55 \cdot 4$ & $44 \cdot 9$ & $60 \cdot 5$ & $48 \cdot 1$ & $57 \cdot 3$ & $60 \cdot 0$ & $57 \cdot 9$ & $46 \cdot 7$ & $54 \cdot 4$ \\
\hline Sheffield* & - & $70 \cdot 3$ & - & $56 \cdot 1$ & - & $36 \cdot 6$ & - & $52 \cdot 2$ & $54 \cdot 3$ \\
\hline Truro & $52 \cdot 8$ & $63 \cdot 3$ & $48 \cdot 3$ & $54 \cdot 7$ & $50 \cdot 0$ & $47 \cdot 1$ & $50 \cdot 7$ & $56 \cdot 2$ & $52 \cdot 7$ \\
\hline Graz & $49 \cdot 6$ & $83 \cdot 2$ & $37 \cdot 9$ & 55.9 & $31 \cdot 6$ & $33 \cdot 1$ & $38 \cdot 7$ & $51 \cdot 6$ & $48 \cdot 6$ \\
\hline Oviedo & $51 \cdot 8$ & $67 \cdot 1$ & $46 \cdot 6$ & $55 \cdot 4$ & $31 \cdot 3$ & $36 \cdot 3$ & $41 \cdot 2$ & $49 \cdot 7$ & $48 \cdot 1$ \\
\hline Leuven & $41 \cdot 1$ & $50 \cdot 9$ & $39 \cdot 4$ & $50 \cdot 3$ & $32 \cdot 1$ & $28 \cdot 1$ & $37 \cdot 8$ & $44 \cdot 0$ & $40 \cdot 3$ \\
\hline Siena & $38 \cdot 3$ & $41 \cdot 8$ & $36 \cdot 0$ & $43 \cdot 6$ & $29 \cdot 4$ & $30 \cdot 2$ & $34 \cdot 2$ & $37 \cdot 3$ & $36 \cdot 6$ \\
\hline Barcelona & $15 \cdot 6$ & $17 \cdot 5$ & $24 \cdot 2$ & $12 \cdot 2$ & $19 \cdot 0$ & $15 \cdot 8$ & $19 \cdot 8$ & $15 \cdot 3$ & $17 \cdot 4$ \\
\hline Athens & $6 \cdot 7$ & $26 \cdot 0$ & $11 \cdot 0$ & $23 \cdot 5$ & $7 \cdot 5$ & $13 \cdot 8$ & $8 \cdot 6$ & $22 \cdot 1$ & $14 \cdot 8$ \\
\hline Las Palmas & $6 \cdot 1$ & $21 \cdot 8$ & $13 \cdot 0$ & $15 \cdot 5$ & $9 \cdot 3$ & $7 \cdot 7$ & $8 \cdot 4$ & $16 \cdot 8$ & $12 \cdot 2$ \\
\hline Madrid & $9 \cdot 7$ & $16 \cdot 6$ & $10 \cdot 5$ & $8 \cdot 4$ & $3 \cdot 9$ & $3 \cdot 8$ & $7 \cdot 7$ & $8 \cdot 7$ & $8 \cdot 8$ \\
\hline Milan & $2 \cdot 5$ & $10 \cdot 3$ & $5 \cdot 4$ & $6 \cdot 6$ & $3 \cdot 3$ & $4 \cdot 1$ & $3 \cdot 7$ & $7 \cdot 0$ & $5 \cdot 4$ \\
\hline EVOS total & $36 \cdot 8$ & $45 \cdot 8$ & $38 \cdot 4$ & $40 \cdot 2$ & $30 \cdot 3$ & $30 \cdot 9$ & $35 \cdot 4$ & $39 \cdot 7$ & $37 \cdot 1$ \\
\hline Centre mean & $48 \cdot 8$ & $59 \cdot 2$ & $50 \cdot 5$ & $53 \cdot 1$ & $43 \cdot 7$ & $42 \cdot 4$ & $47 \cdot 6$ & $50 \cdot 7$ & $49 \cdot 7$ \\
\hline
\end{tabular}

* This centre recruited women only.

t See text.

GERMAN CENTRES

The response rates for the German centres are shown in table 6 , and rates in relation to age and sex in four centres where data were available in table 7 . Because of the differences in the method of survey, the data from these centres are not directly comparable with the non-German centres. It is interesting, however, that the response rates - mean response rate $51 \%$ (range $43-61 \%$ ) - and the pattern of response in relation to age and sex were broadly similar to the non-German centres, though in contrast to most other centres, the response rate in men declined from age 50 onwards.

\section{Discussion}

There are few published data on the major question addressed in this analysis - to what extent do response rates in epidemiological studies vary across different population samples using standard sampling and survey methods? In this multicentre, multinational population survey, despite attempts at a standardised approach, the response rates varied widely between centres and the extent to which the variability in survey technique may be further reduced seems constrained by the practicalities of this type of study.

Clearly, we are unable to comment on whether similar results would have been obtained if the survey had required postal questionnaires rather than attendance for interview and $x$ ray screening. In EVOS, interviewers were used to obtain lifestyle and related information in an attempt to increase the quality

Table 4 Number of subjects who responded to the first letter of invitation and those who responded to any subsequent letter for each centre

\begin{tabular}{|c|c|c|c|c|c|c|}
\hline Centre & No 1st time & No surveyed & Rate (\%) & No 2nd time & No surveyed & Rate (\%) \\
\hline Oporto & 209 & 251 & $83 \cdot 3$ & & - & \\
\hline Malmö & 557 & 764 & $72 \cdot 9$ & 41 & 207 & $19 \cdot 8$ \\
\hline Budapest & 586 & 908 & $64 \cdot 5$ & 55 & 322 & $17 \cdot 1$ \\
\hline Montçeau & 492 & 820 & $60 \cdot 0$ & 70 & 328 & $21 \cdot 3$ \\
\hline Oslo & 557 & 911 & $61 \cdot 1$ & 42 & 354 & 11.9 \\
\hline Moscow & 510 & 790 & $64 \cdot 6$ & 10 & 280 & $3 \cdot 6$ \\
\hline Piestany & 583 & 971 & $60 \cdot 0$ & 54 & 388 & $13 \cdot 9$ \\
\hline Warsaw & 595 & 976 & $61 \cdot 0$ & 15 & 381 & 3.9 \\
\hline Aberdeen & 463 & 822 & $56 \cdot 3$ & 37 & 359 & $10 \cdot 3$ \\
\hline Cambridge & 265 & $498^{*}$ & $53 \cdot 2$ & 53 & 233 & $22 \cdot 7$ \\
\hline Zagreb & 182 & 396 & $46 \cdot 0$ & 44 & 214 & $20 \cdot 6$ \\
\hline Szczecin & 485 & 973 & $49 \cdot 8$ & 50 & 488 & $10 \cdot 2$ \\
\hline Bath & 205 & 390 & $52 \cdot 6$ & 8 & 185 & $4 \cdot 3$ \\
\hline Prague & 420 & 859 & $48 \cdot 9$ & 38 & 439 & $8 \cdot 7$ \\
\hline Truro & 436 & 865 & $50 \cdot 4$ & 18 & 429 & $4 \cdot 2$ \\
\hline Sheffield & 341 & 718 & 47.5 & 34 & 377 & $9 \cdot 0$ \\
\hline Harrow & 325 & 714 & $45 \cdot 5$ & 2 & 389 & 0.5 \\
\hline Oviedo & 518 & 1383 & $37 \cdot 5$ & 106 & 865 & $12 \cdot 3$ \\
\hline Graz & 536 & 1370 & $39 \cdot 1$ & 82 & 834 & $9 \cdot 8$ \\
\hline Leuven & 322 & 1103 & $29 \cdot 2$ & 131 & 781 & $16 \cdot 8$ \\
\hline Siena & 512 & 1696 & $30 \cdot 2$ & 94 & 1184 & 7.9 \\
\hline Barcelona & 86 & 498 & $17 \cdot 3$ & 1 & 412 & $0 \cdot 2$ \\
\hline Athens & 105 & 2467 & $4 \cdot 3$ & 295 & 2362 & $12 \cdot 5$ \\
\hline Las Palmas & 152 & 1934 & $7 \cdot 9$ & 120 & 1782 & $6 \cdot 7$ \\
\hline Madrid & 429 & 5670 & $7 \cdot 6$ & 36 & 5241 & $0 \cdot 7$ \\
\hline Milan & 78 & 1453 & $5 \cdot 4$ & - & & \\
\hline EVOS total & 9949 & 30200 & $32 \cdot 9$ & 1436 & 18834 & $7 \cdot 6$ \\
\hline Centre mean & 383 & 1162 & $44 \cdot 5$ & 60 & 785 & $10 \cdot 4$ \\
\hline
\end{tabular}

* Data on timing of response missing from 83 of this centre's subjects surveyed. 


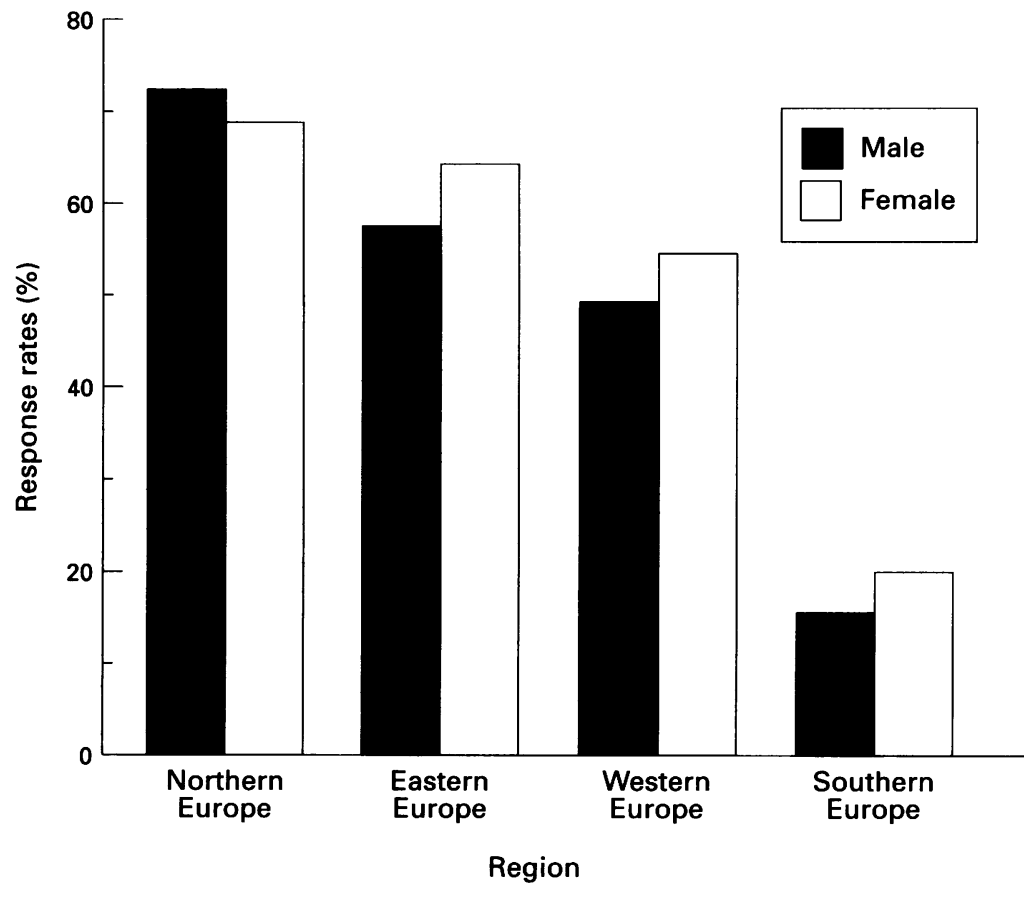

Response rates in relation to sex and region of Europe

of the data ${ }^{1}$ and because equal levels of literacy could not be ensured across the different populations.

A number of techniques was used in this study to try to increase response rates: and hence the rates obtained perhaps represent the realistic likely maximum achievable for this type of survey. Centres were encouraged to publicise the study in the local media. Guidelines were given regarding the letter of invitation, together with the reply and appointment systems, to facilitate individual attendance consistent with the available resources.

Some of the differences were expected in that response rates were generally higher in women than men and declined with increasing age. The latter is likely to be explained, at least partly, by participation involving a visit to a hospital or health centre, an action more difficult for the elderly. The sex difference was probably related to both different awareness of the problem of osteoporosis between men and women, and, particularly in the younger age groups, work responsibilities limiting attendance in men.

There were major geographical differences. Response rates were higher in northern European centres than in the south, and similar in east and western Europe. Within these broad regional patterns, however, there was quite wide variation both within and between countries. In western Europe, for example, the response rate varied from $41 \%$ in Belgium (Leuven) to $68 \%$ in France (Montçeau-LesMines). In Italy, the rate in Sienna was much higher than that in Milan.

The central question in interpreting these data is whether the response rate differences truly represent differing responses from geographically and culturally diverse population groups to a similarly formulated request for attendance or whether persisting "structural" differences, resistant to standardisation, were responsible. Data from single population studies indicate that response rates in epidemiological surveys are influenced by a variety of factors including the nature of the population, including social factors ${ }^{2}$ and urban/rural setting; ${ }^{3}$ the accuracy of the sampling frame; $;^{45}$ and the specific requirements to enable the individual to participate including concerns about safety, confidentiality, accessibility, and convenience of the centre for attendance. These aspects will be considered in turn.

All of the centres in the study were urban and most were situated in or close to university cities. The broad question of urban $v$ rural influence is therefore probably not an important factor in explaining these data. There were substantial social differences, many of which reflect differences in development between countries. In this regard it is of interest to note

Table 5 Response rates in relation to age and sex for each region of Europe

\begin{tabular}{|c|c|c|c|c|c|c|c|c|c|}
\hline \multirow[t]{2}{*}{ Region } & \multicolumn{8}{|c|}{ Age and sex groupings } & \multirow[b]{2}{*}{ Standardised ${ }^{*}$} \\
\hline & $\begin{array}{l}50-59 y \\
M(\%)\end{array}$ & $F(\%)$ & $\begin{array}{l}60-69 y \\
M(\%)\end{array}$ & $F(\%)$ & $\begin{array}{l}70+y \\
M(\%)\end{array}$ & $F(\%)$ & $\begin{array}{l}\text { All ages } \\
M(\%)\end{array}$ & $F(\%)$ & \\
\hline $\begin{array}{l}\text { North } \\
\text { East } \\
\text { West } \\
\text { South }\end{array}$ & $\begin{array}{l}76 \cdot 7 \\
65 \cdot 3 \\
52 \cdot 7 \\
16 \cdot 3\end{array}$ & $\begin{array}{l}76 \cdot 4 \\
66 \cdot 5 \\
68 \cdot 6 \\
25 \cdot 9\end{array}$ & $\begin{array}{l}77 \cdot 5 \\
63 \cdot 3 \\
51 \cdot 6 \\
18 \cdot 9\end{array}$ & $\begin{array}{l}72 \cdot 0 \\
64 \cdot 7 \\
59 \cdot 6 \\
19 \cdot 9\end{array}$ & $\begin{array}{l}67 \cdot 1 \\
56 \cdot 9 \\
45 \cdot 7 \\
12 \cdot 3\end{array}$ & $\begin{array}{l}62 \cdot 6 \\
59 \cdot 9 \\
40 \cdot 9 \\
13 \cdot 7\end{array}$ & $\begin{array}{l}73 \cdot 3 \\
58 \cdot 3 \\
50 \cdot 0 \\
15 \cdot 6\end{array}$ & $\begin{array}{l}69 \cdot 7 \\
65 \cdot 4 \\
55 \cdot 5 \\
19 \cdot 8\end{array}$ & $\begin{array}{l}72 \cdot 1 \\
62 \cdot 8 \\
53 \cdot 2 \\
17 \cdot 8\end{array}$ \\
\hline $\begin{array}{l}\text { EVOS total } \\
\text { Region mean }\end{array}$ & $\begin{array}{l}36 \cdot 8 \\
52 \cdot 8\end{array}$ & $\begin{array}{l}45 \cdot 8 \\
59 \cdot 4\end{array}$ & $\begin{array}{l}39 \cdot 2 \\
52 \cdot 8\end{array}$ & $\begin{array}{l}40 \cdot 2 \\
54 \cdot 1\end{array}$ & $\begin{array}{l}30 \cdot 3 \\
45 \cdot 5\end{array}$ & $\begin{array}{l}30 \cdot 9 \\
44 \cdot 3\end{array}$ & $\begin{array}{l}35 \cdot 4 \\
49 \cdot 3\end{array}$ & $\begin{array}{l}39 \cdot 7 \\
52 \cdot 6\end{array}$ & $\begin{array}{l}36 \cdot 5 \\
51 \cdot 5\end{array}$ \\
\hline
\end{tabular}

* See text.

Table 6 Overall participation rates for German centres

\begin{tabular}{|c|c|c|c|c|c|c|}
\hline Centre & No surveyed & $\begin{array}{l}\text { Response to } \\
\text { postal survey }\end{array}$ & $\begin{array}{l}\text { No of } \\
\text { participants }\end{array}$ & Crude rate (\%) & $\begin{array}{l}\text { Died or moved } \\
\text { house }\end{array}$ & $\begin{array}{l}\text { Corrected rate } \\
(\%)\end{array}$ \\
\hline $\begin{array}{l}\text { Bochum } \\
\text { Potsdam } \\
\text { Steglitz } \\
\text { Lubeck } \\
\text { Heidelberg } \\
\text { Jena } \\
\text { Erfurt } \\
\text { Charite }\end{array}$ & $\begin{array}{l}1200 \\
1100 \\
1228 \\
1156 \\
1072 \\
1200 \\
1209 \\
1200\end{array}$ & $\begin{array}{l}752 \\
442 \\
924 \\
823 \\
799 \\
676 \\
678 \\
808\end{array}$ & $\begin{array}{l}535 \\
481 \\
516 \\
644 \\
606 \\
606 \\
576 \\
492\end{array}$ & $\begin{array}{l}44 \cdot 6 \\
43 \cdot 7 \\
42 \cdot 0 \\
55 \cdot 7 \\
56 \cdot 5 \\
50 \cdot 5 \\
47 \cdot 6 \\
41 \cdot 0\end{array}$ & $\begin{array}{r}72 \\
137 \\
167 \\
58 \\
76 \\
60 \\
- \\
53\end{array}$ & $\begin{array}{l}47 \cdot 4 \\
49 \cdot 9 \\
48 \cdot 6 \\
58 \cdot 7 \\
60 \cdot 8 \\
53 \cdot 2 \\
47 \cdot 6 \\
42 \cdot 9\end{array}$ \\
\hline $\begin{array}{l}\text { EVOS total } \\
\text { Centre mean }\end{array}$ & $\begin{array}{l}9365 \\
1171\end{array}$ & $\begin{array}{r}5902 \\
738 \\
\end{array}$ & $\begin{array}{r}4456 \\
557 \\
\end{array}$ & $\begin{array}{l}47 \cdot 6 \\
47 \cdot 7 \\
\end{array}$ & $\begin{array}{r}623 \\
89 \\
\end{array}$ & $\begin{array}{l}51 \cdot 0 \\
51 \cdot 1 \\
\end{array}$ \\
\hline
\end{tabular}


Table 7 Participation rates in relation to age and sex for four German centres

\begin{tabular}{|c|c|c|c|c|c|c|c|c|c|}
\hline \multirow[t]{2}{*}{ Centre } & \multicolumn{8}{|c|}{ Age and sex groupings } & \multirow[b]{2}{*}{ Standardised ${ }^{*}$} \\
\hline & $\begin{array}{l}50-59 y \\
M(\%)\end{array}$ & $F(\%)$ & $\begin{array}{l}60-69 y \\
M(\%)\end{array}$ & $F(\%)$ & $\begin{array}{l}70+y \\
M(\%)\end{array}$ & $F(\%)$ & $\begin{array}{l}\text { All ages } \\
M(\%)\end{array}$ & $F(\%)$ & \\
\hline $\begin{array}{l}\text { Bochum } \\
\text { Lubeck } \\
\text { Heidelberg } \\
\text { Charite }\end{array}$ & $\begin{array}{l}64 \cdot 2 \\
65 \cdot 7 \\
62 \cdot 5 \\
41 \cdot 7\end{array}$ & $\begin{array}{l}58 \cdot 6 \\
65 \cdot 4 \\
76 \cdot 6 \\
57 \cdot 2\end{array}$ & $\begin{array}{l}52 \cdot 8 \\
61 \cdot 6 \\
61 \cdot 8 \\
46 \cdot 4\end{array}$ & $\begin{array}{l}44 \cdot 4 \\
54 \cdot 9 \\
57 \cdot 6 \\
50 \cdot 5\end{array}$ & $\begin{array}{l}35 \cdot 1 \\
54 \cdot 8 \\
49 \cdot 6 \\
32 \cdot 3\end{array}$ & $\begin{array}{l}21 \cdot 7 \\
33.7 \\
43.0 \\
21.7\end{array}$ & $\begin{array}{l}49 \cdot 3 \\
60 \cdot 6 \\
56 \cdot 7 \\
50 \cdot 3\end{array}$ & $\begin{array}{l}39 \cdot 8 \\
50 \cdot 9 \\
44 \cdot 6 \\
42 \cdot 2\end{array}$ & $\begin{array}{l}46 \cdot 1 \\
56 \cdot 0 \\
58 \cdot 5 \\
41 \cdot 6\end{array}$ \\
\hline $\begin{array}{l}\text { EVOS total } \\
\text { Centre mean }\end{array}$ & $\begin{array}{l}58 \cdot 1 \\
58 \cdot 5\end{array}$ & $\begin{array}{l}63 \cdot 8 \\
64 \cdot 5\end{array}$ & $\begin{array}{l}55 \cdot 4 \\
55 \cdot 6\end{array}$ & $\begin{array}{l}51 \cdot 6 \\
51.9\end{array}$ & $\begin{array}{l}42 \cdot 7 \\
42 \cdot 9\end{array}$ & $\begin{array}{l}30 \cdot 0 \\
30 \cdot 0\end{array}$ & $\begin{array}{l}51 \cdot 4 \\
54 \cdot 2\end{array}$ & $\begin{array}{l}47 \cdot 0 \\
44 \cdot 4\end{array}$ & $\begin{array}{l}50 \cdot 3 \\
50 \cdot 6\end{array}$ \\
\hline
\end{tabular}

* See text.

that response rates from western Europe were less than those of the less developed eastern European countries though the rates in both groups were substantially higher than those from southern Europe.

In household surveys that involve a mailed invitation, an accurate current address is vital. In some centres a guide to the proportion of wrong addresses may be gauged by the level of post office returns. Where such data were available, the response rates were adjusted to exclude those known not to have received an invitation (table 2). However, studies from the $\mathrm{UK}^{67}$ suggest that post office returns underestimate the true problem of register errors and this is likely to be mirrored in other countries. Factors that influence register errors include the currency of the register, the perceived local benefits from being registered (or by contrast the legal sanctions for inaccurate registration), and the population mobility. It would have proved difficult to evaluate accurately the effects of these aspects in the current study. Instead, the sampling frames were chosen pragmatically as being that register, available to each centre, in its most up to date form, which covered the local population as representatively as possible.

Ideally, the non-responders could have been surveyed to determine those who had died or moved house - data not revealed by post office returns. In addition to the cost of such an exercise, practical constraints meant that it would have been impossible to obtain these data: few countries have the same facilities as the UK in its National Health Service Central Register, which permits relatively easy tracing of those who move house or die.

There seemed to be evidence from this study that using a register derived for health purposes as the sampling frame is associated with a higher response rate (tables 1 and 2). Although this might reflect the fact that these registers are more accurate than "generic" population registers, there may be an alternative explanation. Thus, a request received for health screening under the aegis of the health facility providing routine health care (and possibly under its letterhead) may be more likely to result in positive action by the target population.

Participating centres were responsible for organising the screening in their own centre, and despite the standardised approach small differences in recruitment and appointment methods may have accounted for some of the response rate variation. ${ }^{8-11}$ Structural factors such as the distance and availability of transport may have accounted for some variation. Crude distances are a poor proxy for accessibility and the target population for most centres was chosen, again pragmatically, on the basis of the screening facility being one considered to be within the population's normal travelling time.

Other factors that may have been responsible for the variation between centres include the literacy of the population (first contact was through a letter of invitation) and specific local anxiety about radiographs and the consequent $x$ ray exposure.

The main purpose behind attempts to obtain high response rates in epidemiological studies is to increase the likelihood that the population sampled is representative and therefore free from selection or non-response bias. ${ }^{3}$ While high response rates suggest that the population is truly representative, however, it does not necessarily follow that a low response rate will result in a biased sample or, conversely, that a high response rate will result in an unbiased sample. ${ }^{12}$ In order to assess this properly, it is necessary to obtain data from larger representative samples of non-responders; however, this is costly and not often practical. Multinational studies play an increasingly important role in epidemiological research. The interpretation of results from these studies needs to take into consideration the possibility of non-response bias occurring to differing extents between centres because of differences in response rates.

In conclusion, there are a number of major influences on response rates to health surveys involving attendance for screening between European populations. These factors will include both true population differences as well as inherent differences in survey methodology. Attempts at cross national standardisation in survey design can have only a limited effect on yielding uniformity in response.

The European Vertebral Osteoporosis Study Project Management Group

AJ Silman (Manchester) (project leader); D Agnusdei (Siena); (Manchester) (project leader); D Agnusdei (Siena) Cooper (Southampton); J Dequeker (Leuven); D Felsenber (Berlin); J Kanis (Sheffield); G Kruskemper (Bochum); H Raspe Community COMAC-EPID programme)

Principal investigators

Austria: Graz, T Lauermann, $\mathrm{K}$ Weber; Belgium: Leuven, Dequeker, P Geusens; Croatia: Zagreb, I Jajic; Czech Republic/Slovakia: Prague, S Havelka, P Vavrincova, Piestany A Letkovska, P Masaryk; France: Monţ̧eau-Les-Mines, PD Delmas, F Marchand; Germany: Berlin Steglitz, D Felsenberg, Berlin Potsdam, D Banzer, Berlin Charite, S Kirschner, W Reisinger, Bochum, J Janott, H Schatz, Erfurt, J Franke, Heidelberg, C Scheidt-Nave, R Ziegler, fena, K Abendroth, B Felsch, Lubeck, C Matthis, H Raspe; Greece: Athens, A Antoniou, G Lyritis; Hungary: Budapest, C Kiss, G Poor; Italy: Siena, D Agnusdei, C Gennari, Milan, S Ortolani; Netherlands: Rotterdam, A Hofman, HAP Pols; Norway: Oslo, JA Falch, HE Meyer; Poland: Szczecin, S Czekalski, T Miazgowski, Warsarw, 
K Hoszowski, RS Lorenc; Portugal: Oporto, A Aroso, A Lopez Vaz; Russia: Moscow, LI Benevolenskaya, EE Mikhailov; Spain Barcelona, D Roig Escofet, M Ruiz Martin, Canary Islands, M Sosa, Madrid, M Diaz Curiel, A Rapado, Oviedo, JB Cannat Andia, JB Diaz Lopez; Sweden: Malmö, O Johnell, B Nilsson Turkey: Istanbul, G Dilsen; United Kingdom: Aberdeen, DM Reid, Bath, AK Bhalla, F Ring, Cambridge, C Todd, R Williams, Harrow, J Reeve, Sheffield, R Eastell, Truro, AD Woolf.

\section{Other investigators}

The authors acknowledge the contribution of the following individuals.

Austria: Graz, GJ Krejs, G Leb, A Lederer, W Radkohl, R Rienmuller, H Schreyer, H Toplak; Belgium: Leuven, K Van den Bremt, J Nijs; Croatia: Zagreb, M Dubravica, S Gligora Z Jajic, A Sucur; Czech Republic/Slovakia: Prague, M Linduskova, Piestany, E Brisudova, T Hornakova, E Martancikova, J Tomkuljakova; France: Montçeau-Les-Mines, Societé de Secours Minière de Bourgogne; Germany: Berlin Steglitz, I KellerJanker, B Rothenburg, Berlin Potsdam, C Popovici, Bochum, M Bohle, S Hering, A Pfeiffer, A Weber, V Wiebe, H Seelbach, Erfurt, M Angrick, C Dodenhof, Heidelbeng, G Leidig-Bruckner B Limberg, fena, G Lehmann, I Marzoll, Lubeck, A Raspe, E B Limberg, fena, G Lehmann, I Marzoll, Lubeck, A Raspe, E Petta; Italy: Milan, F Ulivieri, Siena, C De Bedin, F Castellani, Petta; Italy: Milan, F Ulivieri, Siena, C De Bedin, F Castellani, D Gerardi, P Sacco, P Terrosi Vagnoli; Netherlands: Rotterdam, E Gromniak, A Krzysztalowski, K Napierata, J Ogonowski, Warsaw, J Gawron, T Grabski, J Jedrzejewska, P Korczyk, J Warsaw, J Gawron, T Grabski, J Jedrzejewska, P Korczyk, Vaz; Russia: Moscow, NM Milov; Spain: Canary Islands, D Gonzalez, Madrid, J Ortega, Oviedo, C Gomez Alonso, M Naves Diaz, B Fernandez, JR Jimenez, MJ Virgos Soriano; Sweden Malmö, A Rafstedt; Turkey: Istanbul, R Aydin; United Kingdom: Aberdeen, R Smith, Bath, D Elvins, R Palmer, Cambridge, B Gurney, A Martin, Harrow, A Nicholls, C Oxbrough, L Peter, $\mathrm{O}$ Waldron, J Walton, K Walton, Sheffeld, D Greenfield, Truro, A Deodhar, J Parsons.

The study was financially supported by a central coordination grant from the European Community's Concerted Action in Epidemiology Program. The central coordination was also supported by the European Foundation for Osteoporosis and Bone Disease and the UK Arthritis and Rheumatism Council. In- dividual participating centres acknowledge the receipt of locally acquired support for their data collection.

1 O'Toole BI, Battistutta D, Long A, Crouch K. A comparison of costs and data quality of three health survey methods: mail, telephone and personal home interview. Am $\mathcal{f} E p$ idemiol 1986;124:317-28.

2 Kaplan S, Cole P. Factors affecting response to postal questionnaires. Br F Prev Soc Med 1970;24:245-7.

3 Alderson $M$. An introduction to epidemiology. 2nd ed. London: Macmillan Press, 1983.

4 Sheldon MG, Rector AL, Barnes PA. The accuracy of agesex registers in general practice. $\mathcal{F}$ Roy Coll Gen Pract 1984; 34:269-71.

5 Bowling A, Hart D, Silman A. Accuracy of electoral registers and family practitioner committee lists for population studies of the very elderly. $\mathcal{F}$ Epidemiol Community Health 1989;43:391-4.

6 Silman AJ. Age-sex registers as a screening tool for general practice: size of the wrong address problem. $B M \mathcal{F} 1984$; 289:415.

7 Bickler G, Sutton S. Inaccuracy of FHSA registers: help from electoral registers. BMF 1993;306:1167.

8 Garton MJ, Torgerson DJ, Donaldson C, Russell IT, Reid DM. Recruitment methods for screening programmes: trial of a new method within a regional osteoporosis study. BMF 1992;305:82-4.

9 Maheux B, Legault C, Lambert J. Increasing response rates in physicians mail surveys: an experimental study. $A m \mathcal{F}$ in physicians mail surveys: an

10 Smith WCS, Crombie IK, Campion PD, Knox JDE. Comparison of response rates to a postal questionnaire from a general practice and a research unit. $B M F 1985 ; 291$ 1483-5.

11 Wilson A, Leeming A. Cervical cytology screening: a comparison of two call systems. BMF 1987;295:181-2.

12 Sheikh K, Mattingly S. Investigating non-response bias in mail surveys. $\mathcal{f}$ Epidemiol Community Health 1981;35: 293-6.

Since this went to press, further recruitment in 2 UK centres resulted in increased response rates: Harrow, $55 \%$ and Cambridge, $67 \%$. 